\title{
Nitromethane encephalopathy MRI
}

Figure T2-weighted fluid attenuated inversion recovery axial (A, B), coronal (C), and sagittal (D) sections showing bilateral and symmetric hyperintense lesions in cerebellar white matter, tonsils, uvula, and tectum
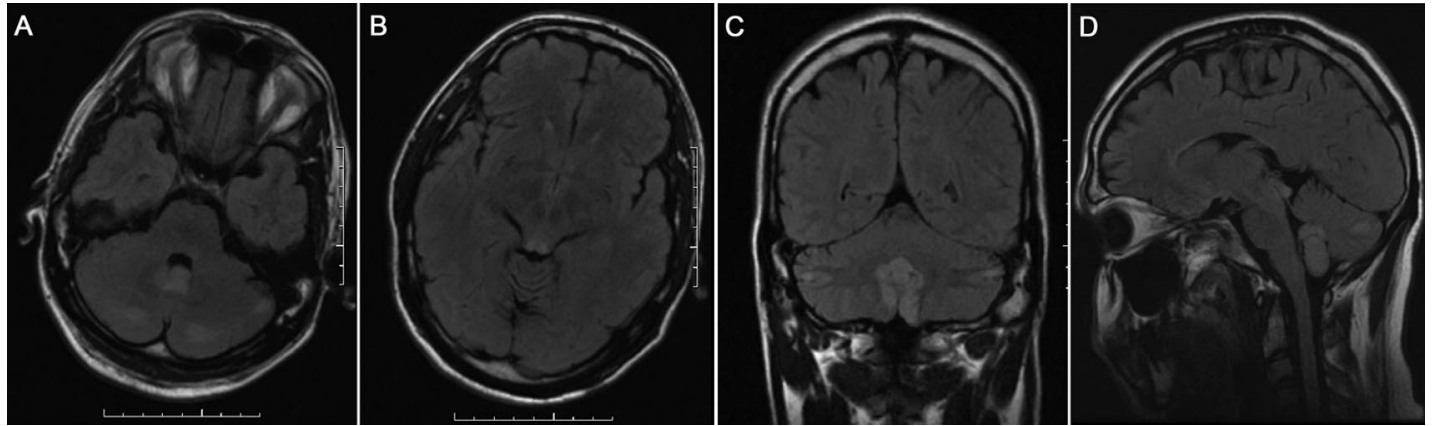

These lesions were less conspicuous on T2-weighted images. Symmetric lesions support the diagnosis of toxic encephalopathy.

After nitromethane fuel ingestion, an 18-year-old male mechanic presented with generalized tonicclonic seizures progressing to partial motor status epilepticus. At physical examination hypertension was noted. Symptomatic therapy was initiated, including valproic acid, $\beta$-blockers, and clonidine. When neurologic examination could be performed, it showed mild left dysmetria in finger-to-nose testing, low-frequency intention tremor, broad-based gait, and inability to tandem-walk. MRI (figure) demonstrated bilateral and symmetric lesions in cerebellar white matter, tonsils, uvula, and colliculi. Valproic acid was maintained. Clinical and MRI 8-month follow-up showed no abnormalities. To our knowledge, this is the first documented case of reversible encephalopathy by nitromethane ingestion. ${ }^{1,2}$

Elena Alventosa Fernández, MD, Candelaria González González, MD, Javier Crisóstomo Pardillo, MD, Vicente Martín García, MD, Santa Cruz de Tenerife, Spain

Disclosure: The authors report no conflicts of interest.

Address correspondence and reprint requests to Dr. Elena Alventosa Fernández, C/Santa Rosalía, 5-3ㅇ, 38002 Santa Cruz de Tenerife, Spain; elena.alventosa@gmail.com814814

1. Sclar G. Encephalomyeloradiculoneuropathy following exposure to an industrial solvent. Clin Neurol Neurosurg 1999; 101:199-202.

2. Booth C, Naidoo D, Rosengerg A, Kainer G. Elevated creatinine after ingestion of model aviation fuel: interference with the Jaffe reaction by nitromethane. J Paediatr Child Health 1990;35:503-504. 


\section{Neurology}

\section{Nitromethane encephalopathy MRI}

Elena Alventosa Fernández, Candelaria González González, Javier Crisóstomo Pardillo, et al.

Neurology 2008;70;814

DOI 10.1212/01.wnl.0000304254.18355.b3

\section{This information is current as of March 3, 2008}

\section{Updated Information \&} Services

References

Citations

Subspecialty Collections

Permissions \& Licensing

Reprints including high resolution figures, can be found at: http://n.neurology.org/content/70/10/814.full

This article cites 2 articles, 0 of which you can access for free at: http://n.neurology.org/content/70/10/814.full\#ref-list-1

This article has been cited by 1 HighWire-hosted articles: http://n.neurology.org/content/70/10/814.full\#\#otherarticles

This article, along with others on similar topics, appears in the following collection(s):

MRI

http://n.neurology.org/cgi/collection/mri

Other toxicology

http://n.neurology.org/cgi/collection/other_toxicology

Solvents

http://n.neurology.org/cgi/collection/solvents

Information about reproducing this article in parts (figures,tables) or in its entirety can be found online at:

http://www.neurology.org/about/about_the_journal\#permissions

Information about ordering reprints can be found online:

http://n.neurology.org/subscribers/advertise

Neurology ${ }^{\circledR}$ is the official journal of the American Academy of Neurology. Published continuously since 1951, it is now a weekly with 48 issues per year. Copyright. All rights reserved. Print ISSN: 0028-3878. Online ISSN: 1526-632X.

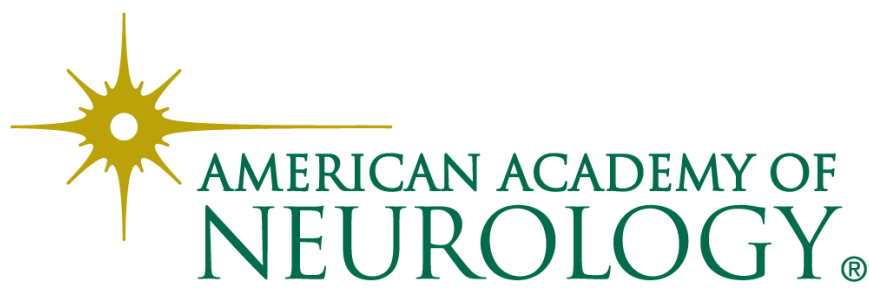

